\title{
Perbedaan asupan mikronutrien pada lansia penderita hipertensi esensial yang overweight dan tidak overweight
}

Different intake of micronutrients in overweight and non overweight elderly with essential hypertension

Catur Saptaning Wilujeng ${ }^{1}$, Wasilah Rochmah ${ }^{2}$, Susetyowati $^{3}$

\begin{abstract}
Background: Hypertension in overweight elderly is a crucial problem considering that its pathogenesis, disease pattern and management are not entirely the same with hypertension in young adults. Hypertension in overweight elderly requires particular attention because it is closely associated with overall management (medical and nutritional). Objective: To study different intake of micronutrients, i.e. natrium ( $\mathrm{Na}$ ), potassium ( $\mathrm{K})$, calcium ( $\mathrm{Ca}$ ), and magnesium $(\mathrm{Mg})$ in overweight and non overweight elderly with essential hypertension at Griya Sehat Lansia (GSL) Yogyakarta. Method: The study was analytical with case control study design. Samples were as many as 138 elderly of 60-75 years old taken using multistage sampling technique. Data of intake Na, K, $\mathrm{Ca}, \mathrm{Mg}$ were obtained through semi quantitative food frequency questionnaire (FFQ); essential hypertension through assessment of blood pressure using sphygmomanometer; overweight and non overweight status through body mass index (BMI), BMI for overweight was 23-24.9 kg/m and non-overweight was $18.50-22.99 \mathrm{~kg} / \mathrm{m}^{2}$. Statistical analysis used paired test, Chi-Square and logistic regression. Results: There were differences in intake of $\mathrm{Na}, \mathrm{K}, \mathrm{Ca}$, and $\mathrm{Mg}$ between overweight and non overweight elderly $(p<0.05)$. There were significant association $(p<0.05)$ between intake of $\mathrm{Na}, \mathrm{K}, \mathrm{Ca}$, and $\mathrm{Mg}$ of overweight and non overweight elderly with essential hypertension, with OR 5.271; 6.813; 3.398 and 3.444. Intake of Na and K were variables most significantly associated with overweight and non overweight elderly with essential hypertension $(p<0.05)$. Conclusion: There were significant differences in intake of micronutrients ( $\mathrm{Na}, \mathrm{K}, \mathrm{Ca}, \mathrm{Mg}$ ) between overweight and non overweight elderly with essential hypertension at GSL Yogyakarta.
\end{abstract}

KEY WORDS: micronutrients, essential hypertension, elderly, overweight

\begin{abstract}
ABSTRAK
Latar belakang: Hipertensi pada lansia yang overweight menjadi suatu masalah kesehatan yang penting mengingat bahwa patogenesis, perjalanan penyakit, dan penatalaksanaannya tidak seluruhnya sama dengan hipertensi pada usia dewasa muda. Hipertensi pada lansia yang overweight perlu mendapatkan perhatian karena berhubungan erat dengan penatalaksanaan secara keseluruhan (medis dan gizi). Tujuan: Mempelajari perbedaan asupan mikronutrien yaitu natrium (Na), kalium (K), kalsium $(\mathrm{Ca})$, dan magnesium $(\mathrm{Mg})$ pada lansia penderita hipertensi esensial yang overweight dan tidak overweight di Griya Sehat Lansia Yogyakarta. Metode: Penelitian analitik dengan rancangan case control study. Sampel penelitian adalah 138 lansia umur 60-75 tahun yang dipilih berdasarkan teknik multistage sampling. Asupan $\mathrm{Na}, \mathrm{K}, \mathrm{Ca}, \mathrm{Mg}$ subjek dikumpulkan dengan semi kuantitatif food frequency questionnaire (FFQ); hipertensi esensial diperoleh dengan mengukur tekanan darah lansia dengan tensimeter; status overweight dan tidak overweight subjek diukur dengan indeks massa tubuh (IMT) yaitu overweight jika $23-24,9 \mathrm{~kg} / \mathrm{m}^{2} \mathrm{dan}$ tidak overweight jika 18,50-22,99 kg/m². Analisis statistik yang digunakan adalah uji t berpasangan, Chi-Square, dan regresi logistik. Hasil: Terdapat perbedaan asupan $\mathrm{Na}, \mathrm{K}, \mathrm{Ca}$, dan $\mathrm{Mg}$ antara lansia overweight dengan lansia tidak overweight $(\mathrm{p}<0,05)$. Terdapat hubungan bermakna $(\mathrm{p}<0,05)$ antara asupan $\mathrm{Na}, \mathrm{K}, \mathrm{Ca}$, dan $\mathrm{Mg}$ pada lansia penderita hipertensi esensial yang overweight dengan yang tidak overweight, dengan OR berturut-turut sebesar 5,271; 6,813;3,398; dan 3,444. Asupan Na dan K merupakan dua variabel yang memiliki hubungan yang paling bermakna pada lansia penderita hipertensi esensial yang overweight dengan lansia yang tidak overweight $(\mathrm{p}<0,05)$. Simpulan: Ada perbedaan yang bermakna asupan mikronutrien $(\mathrm{Na}, \mathrm{K}, \mathrm{Ca}, \mathrm{Mg})$ pada lansia penderita hipertensi esensial yang overweight dan tidak overweight di Griya Sehat Lansia Yogyakarta.
\end{abstract}

KATA KUNCI: mikronutrien, hipertensi esensial, lansia, overweight

\section{PENDAHULUAN}

Di Indonesia, perhatian tentang kesehatan dan kualitas hidup terhadap penduduk lanjut usia (lansia) meningkat, terutama karena jumlahnya yang cenderung
${ }^{1}$ Korespondensi: Program Studi Gizi, Fakultas Kedokteran Universitas Brawijaya Malang, Jl. Veteran Malang, Jawa Timur, e-mail: catursaptaning@yahoo.com

2 Klinik Pelayanan Kesehatan Khusus Lansia Griya Sehat Lansia Yogyakarta, Jl. Parangtritis No. 132-134, Yogyakarta

Program Studi Gizi Kesehatan, Fakultas Kedokteran Universitas Gadjah Mada, Jl. Farmako, Sekip Utara, Yogyakarta 55281, e-mail: susetyowati2000@yahoo.com 
meningkat pesat. Berdasarkan data dari Badan Pusat Statistik Survei Sosial Ekonomi Nasional (BPS-Susenas) tahun 2007, Daerah Istimewa Yogyakarta (DIY) merupakan provinsi dengan persentase lansia tertinggi yaitu sebesar 14,04\% dibandingkan dengan empat provinsi lain di Indonesia yaitu Jawa Tengah 11,16\%, Jawa Timur 11,14\%, Bali 11,02\%, dan Sulawesi Selatan 9,05\%.

Orang yang berusia lanjut akan mengalami penurunan beberapa fungsi organ tubuh yang dapat menyebabkan penyerapan zat gizi menurun. Keadaan ini tentunya akan mempengaruhi status gizi lansia. Hal ini perlu mendapat perhatian karena salah satu masalah kesehatan yang sekarang ini sering dialami oleh lansia adalah penyakit hipertensi. Hipertensi merupakan salah satu penyakit degeneratif yang mempunyai tingkat morbiditas dan mortalitas tinggi. Hipertensi pada usia lanjut menjadi lebih penting lagi mengingat bahwa patogenesis, perjalanan penyakit, dan penatalaksanaannya tidak seluruhnya sama dengan hipertensi pada usia dewasa muda. Pada usia lanjut, aspek diagnosis selain ke arah hipertensi dan komplikasi, pengenalan berbagai penyakit (komorbid) yang juga diderita oleh lansia tersebut perlu mendapatkan perhatian karena berhubungan erat dengan penatalaksanaan secara keseluruhan (1). Penatalaksanaan ini meliputi segi medis dan aspek gizi. Data riset kesehatan dasar (Riskesdas) tahun 2007 menunjukkan bahwa prevalensi kejadian hipertensi di Provinsi DIY sebesar 35,8\%, yaitu lebih tinggi dibandingkan dengan prevalensi nasional $(31,7 \%)(2)$.

Penyakit hipertensi disebabkan oleh asupan natrium $(\mathrm{Na})$ dalam jumlah yang berlebih dan dalam waktu tertentu. Selain itu, hipertensi juga disebabkan oleh ketidakseimbangan asupan mineral pengatur tekanan darah lainnya yaitu kalium $(\mathrm{K})$, kalsium $(\mathrm{Ca})$, dan magnesium (Mg) (3). Penelitian di Bengkulu menunjukkan bahwa terdapat empat variabel yang secara bermakna berhubungan dengan hipertensi esensial yaitu asupan $\mathrm{Na}$, asupan K, stres, dan obesitas. Asupan tinggi $\mathrm{Na}$, stres, dan obesitas merupakan faktor risiko terjadinya hipertensi esensial pada lansia (4). Penelitian lain juga menyebutkan bahwa dari semua populasi yang diteliti yaitu orang-orang China di perkotaan dengan usia 34-65 tahun, memiliki tingkat konsumsi Na yang tinggi dan $\mathrm{K}$ yang rendah. Hasil penelitian tersebut juga menunjukkan bahwa asupan $\mathrm{Na}$ dan rasio asupan $\mathrm{Na}-\mathrm{K}$ berpengaruh pada kejadian hipertensi (5).

Provinsi DIY adalah provinsi di Indonesia yang mempunyai angka usia harapan hidup yang tinggi yaitu 74,05 tahun (6). Hal ini dapat dikatakan sebagai suatu pencapaian yang membanggakan dalam bidang kesehatan. Namun, hubungan antara asupan zat gizi, status gizi, dan derajat kesehatan pada usia lanjut di DIY masih belum diketahui. Tujuan penelitian ini adalah untuk mempelajari perbedaan asupan mikronutrien yaitu $\mathrm{Na}$, $\mathrm{K}$, $\mathrm{Ca}$, dan $\mathrm{Mg}$ pada lansia penderita hipertensi esensial yang overweight dan tidak overweight.

\section{BAHAN DAN METODE}

Jenis penelitian ini merupakan penelitian analitik dengan rancangan case-control. Penelitian dilakukan di Griya Sehat Lansia (GSL) Yogyakarta pada bulan Januari 2011 sampai dengan bulan Maret 2011. Griya Sehat Lansia Yogyakarta merupakan salah satu pusat pelayanan kesehatan lansia terbesar di Yogyakarta, dengan jumlah lansia yang dilayani lebih dari seribu lansia. Program GSL adalah memberikan pelayanan kesehatan secara rutin kepada lansia dengan pendekatan multidisiplin dan paripurna. Program ini dilaksanakan oleh tenaga kesehatan yang ahli di bidangnya yaitu dokter spesialis dan perawat, serta di bawah pengawasan dan bimbingan dari dokter spesialis konsultan geriatri.

Populasi penelitian adalah seluruh pasien di GSL Yogyakarta baik pasien khusus praktisia maupun pasien di luar praktisia. Pasien praktisia adalah pasien GSL yang mendapat pelayanan kesehatan tanpa biaya (lansia dari paguyuban lansia) dan pelayanan kesehatan dilakukan oleh petugas kesehatan GSL dengan mendatangi paguyuban-paguyuban lansia. Sementara itu, pasien di luar praktisia adalah pasien GSL yang mendapat pelayanan kesehatan dengan biaya dan datang langsung ke GSL. Subjek penelitian ini adalah lansia yang memenuhi kriteria inklusi yaitu usia 60-75 tahun, menderita hipertensi esensial yang diketahui berdasarkan catatan rekam medis, bisa berkomunikasi dengan baik berdasarkan pengamatan dan data dari GSL, serta berjenis kelamin laki-laki atau perempuan. Namun, kriteria 
inklusi khusus untuk kelompok kasus yaitu lansia dengan status gizi overweight (IMT $\geq 23 \mathrm{~kg} / \mathrm{m}^{2}$ ) sedangkan kelompok kontrol adalah lansia dengan status gizi tidak overweight (IMT $<23 \mathrm{~kg} / \mathrm{m}^{2}$ ). Kriteria eksklusi untuk kasus dan kontrol adalah lansia yang menderita penyakit jantung, gagal ginjal, mengkonsumsi obat-obatan untuk penyakit-penyakit tersebut, dan lansia yang mengalami penurunan ingatan (proses pikun). Pada penelitian ini dilakukan penyetaraan umur, jenis kelamin, dan tingkat hipertensi esensial. Penjelasan tingkat hipertensi esensial yang disetarakan adalah hipertensi esensial tingkat 1 $(\leq 140 / 90 \mathrm{mmHg})$ dan hipertensi esensial tingkat 2 (> 140/90 mmHg) (7).

Besar sampel diperoleh berdasarkan rumus dengan tingkat kepercayaan $(Z \alpha)$ 95\%, power $(Z \beta)$ sebesar $80 \%$, dan odds rasio (OR) sebesar 2 (8) sehingga besar sampel minimal adalah 138 lansia yang dibagi menjadi 69 lansia sebagai kasus (lansia penderita hipertensi esensial yang overweight) dan 69 lansia sebagai kontrol (lansia penderita hipertensi esensial yang tidak overweight). Pemilihan sampel penelitian ditentukan dengan cara multistage sampling. Langkah pertama yang dilakukan adalah dengan two stage cluster sampling karena wilayah kerja GSL meliputi daerah perkotaan (Kota Yogyakarta) yang luas sehingga metode ini digunakan dalam pemilihan sampel secara acak pada kelompok individu dalam populasi tersebut. Langkah kedua yaitu melakukan pemilihan sampel lagi dari sampel yang sudah diperoleh dengan menggunakan metode stratified random sampling untuk memperoleh sampel lansia dalam dua kelompok yaitu kelompok kasus dan kontrol (8).

Variabel bebas dalam penelitian ini yaitu asupan $\mathrm{Na}$, $\mathrm{K}$, $\mathrm{Ca}$, dan $\mathrm{Mg}$, variabel tergantungnya adalah status gizi sedangkan variabel luar yang diteliti meliputi terapi obat antihipertensi, konsumsi rokok, dan konsumsi minuman beralkohol. Asupan Na dikategorikan menjadi dua yaitu rendah ( $\mathrm{Na}<2300 \mathrm{mg} /$ hari) dan tinggi $(\mathrm{Na} \geq 2300 \mathrm{mg}$ /hari) (9). Demikian juga asupan K yang dikategorikan menjadi rendah ( $\mathrm{K}<2000 \mathrm{mg} / \mathrm{hari}$ ) dan tinggi ( $\mathrm{K} \geq 2000 \mathrm{mg} / \mathrm{hari}$ ) (10). Asupan $\mathrm{Ca}$ dikategorikan rendah jika asupan $\mathrm{Ca}$ kurang dari $800 \mathrm{mg}$ /hari pada laki-laki dan kurang dari 600 $\mathrm{mg} /$ hari pada perempuan sedangkan dikategorikan tinggi jika asupan Ca lebih dari atau sama dengan $800 \mathrm{mg} /$ hari pada laki-laki dan lebih dari atau sama dengan $600 \mathrm{mg} /$ hari pada perempuan (10). Demikian juga asupan $\mathrm{Mg}$ yang dibedakan menurut jenis kelamin yaitu dikategorikan rendah jika asupan Mg kurang dari $280 \mathrm{mg}$ /hari pada laki-laki dan kurang dari $250 \mathrm{mg}$ /hari pada perempuan sedangkan dikategorikan tinggi jika asupan $\mathrm{Mg}$ lebih dari atau sama dengan $280 \mathrm{mg} /$ hari pada laki-laki dan lebih dari atau sama dengan $250 \mathrm{mg}$ /hari pada perempuan (10).

Status gizi overweight dan tidak overweight diukur dengan rumus indeks massa tubuh (IMT), yaitu berat badan (kilogram) dibagi kuadrat dari tinggi badan (meter). Tinggi badan lansia diperoleh dari pengukuran tinggi lutut yang dikonversikan ke tinggi badan dengan rumus untuk lakilaki yaitu $\{2,02 \mathrm{x}$ tinggi lutut (sentimeter) $\}-\{0,04 \mathrm{x}$ umur (tahun) $\}+64,19$ dan untuk perempuan yaitu $\{1,83 \times$ tinggi lutut (sentimeter) $\}-\{0,24 \mathrm{x}$ umur (tahun) $\}+84,88$. Status gizi overweight pada penelitian ini terdiri dari lansia dengan IMT lebih dari atau sama dengan $23 \mathrm{~kg} / \mathrm{m}^{2}$ (overweight) dan IMT lebih dari atau sama dengan $25 \mathrm{~kg} / \mathrm{m}^{2}$ (obesitas) (11). Namun, selanjutnya status gizi dibedakan menjadi dua yaitu status gizi overweight $\left(\geq 23 \mathrm{~kg} / \mathrm{m}^{2}\right)$ dan tidak overweight $\left(<23 \mathrm{~kg} / \mathrm{m}^{2}\right)$.

Data antropometri diperoleh dari pengukuran berat badan menggunakan timbangan injak dengan skala tingkat validitas $0,1 \mathrm{~kg}$ dan tinggi lutut diukur menggunakan pita meteran dengan tingkat validitas $0,1 \mathrm{~cm}$. Pengukuran tekanan darah dilakukan dengan menggunakan tensimeter air raksa oleh dokter dari dalam dan atau dari luar GSL Yogyakarta. Pengukuran asupan $\mathrm{Na}, \mathrm{K}, \mathrm{Ca}$, dan Mg menggunakan form semi kuantitatif food frequency quesstionaire (FFQ) dan food model. Analisis asupan $\mathrm{Na}, \mathrm{K}, \mathrm{Ca}$, dan $\mathrm{Mg}$ yang telah dicatat di FFQ, dilihat frekuensi makan dan jumlahnya kemudian dikonversikan ke frekuensi makan per hari dan jumlahnya per hari. Setelah itu, dimasukkan ke program nutrisurvey untuk memperoleh nilai asupan dalam satuan $\mathrm{mg} /$ hari. Pengumpulan data dibantu oleh tenaga enumerator yaitu mahasiswa lulusan S1, Profesi Gizi Kesehatan, dan S2 Minat Utama Gizi Kesehatan.

Analisis data untuk menguji hipotesis penelitian ini adalah uji t berpasangan, uji Chi-Square, dan regresi logistik. Penelitian ini telah mendapat persetujuan dari subjek penelitian dengan menandatangani informed consent dan sudah memperoleh persetujuan etik dari Komite Etik Fakultas Kedokteran Universitas Gadjah Mada. 
Tabel 1. Karakteristik subjek penelitian

\begin{tabular}{|c|c|c|c|c|c|c|}
\hline \multirow[t]{2}{*}{ Variabel } & \multicolumn{2}{|c|}{$\begin{array}{l}\text { Kasus } \\
(n=69)\end{array}$} & \multicolumn{2}{|c|}{$\begin{array}{c}\text { Kontrol } \\
(\mathrm{n}=69)\end{array}$} & \multirow[t]{2}{*}{$\chi^{2}$} & \multirow[t]{2}{*}{$\mathbf{p}$} \\
\hline & $\mathbf{n}$ & $\%$ & $\mathbf{n}$ & $\%$ & & \\
\hline \multicolumn{7}{|l|}{ Umur (tahun) } \\
\hline $60-67$ & 43 & 62,3 & 43 & 62,3 & \multirow[t]{2}{*}{0,000} & \multirow[t]{2}{*}{1,000} \\
\hline $68-75$ & 26 & 37,7 & 26 & 37,7 & & \\
\hline \multicolumn{7}{|l|}{ Jenis kelamin } \\
\hline Laki-laki & 18 & 26,1 & 18 & 26,1 & \multirow[t]{2}{*}{0,000} & \multirow[t]{2}{*}{1,000} \\
\hline Perempuan & 51 & 73,9 & 51 & 73,9 & & \\
\hline \multicolumn{7}{|l|}{ Pekerjaan } \\
\hline PNS & 30 & 43,5 & 28 & 40,6 & \multirow[t]{2}{*}{0,119} & \multirow[t]{2}{*}{0,730} \\
\hline Non PNS & 39 & 56,5 & 41 & 59,4 & & \\
\hline \multicolumn{7}{|l|}{ Pendidikan } \\
\hline PT & 4 & 5,8 & 5 & 7,3 & \multirow{5}{*}{0,029} & \multirow{5}{*}{0,865} \\
\hline SLTA & 18 & 26,1 & 17 & 24,6 & & \\
\hline SLTP & 13 & 18,8 & 11 & 15,9 & & \\
\hline SD & 19 & 27,6 & 15 & 21,7 & & \\
\hline Tidak tamat SD & 15 & 21,7 & 21 & 30,5 & & \\
\hline \multicolumn{7}{|l|}{ Penghasilan } \\
\hline$<\operatorname{Rp} 1.000 .000,00$ & 52 & 75,4 & 50 & 72,5 & \multirow[t]{2}{*}{0,150} & \multirow[t]{2}{*}{0,698} \\
\hline$\geq \operatorname{Rp} 1.000 .000,00$ & 17 & 24,6 & 19 & 27,5 & & \\
\hline \multicolumn{7}{|l|}{ Terapi obat antihipertensi } \\
\hline Tidak & 59 & 85,5 & 57 & 82,6 & \multirow[t]{2}{*}{0,216} & \multirow[t]{2}{*}{0,642} \\
\hline $\mathrm{Ya}$ & 10 & 14,5 & 12 & 17,4 & & \\
\hline \multicolumn{7}{|l|}{ Konsumsi rokok } \\
\hline $\mathrm{Ya}$ & 6 & 8,7 & 3 & 4,3 & \multirow[t]{2}{*}{1,070} & \multirow[t]{2}{*}{0,301} \\
\hline Tidak & 63 & 91,3 & 66 & 95,7 & & \\
\hline \multicolumn{7}{|c|}{ Konsumsi minuman beralkohol } \\
\hline $\mathrm{Ya}$ & 3 & 4,3 & 2 & 2,9 & \multirow[t]{2}{*}{0,208} & \multirow[t]{2}{*}{0,649} \\
\hline Tidak & 66 & 95,7 & 67 & 97,1 & & \\
\hline
\end{tabular}

Keterangan: $\chi^{2}=$ uji Chi-Square; $\mathrm{p}<0,05=$ nilai signifikansi

HASIL

\section{Karakteristik subjek penelitian}

Hasil penelitian menunjukkan bahwa tidak ada perbedaan yang bermakna pada pekerjaan, pendidikan, penghasilan, terapi obat antihipertensi, konsumsi rokok, dan konsumsi minuman beralkohol antara lansia penderita hipertensi esensial yang overweight dan tidak overweight. Pekerjaan subjek penelitian yang paling banyak yaitu pekerjaan non pegawai negeri sipil (PNS). Sebagian besar subjek penelitian baik pada kelompok kasus maupun kontrol memiliki tingkat pendidikan rendah atau tidak tamat SMA $(68,1 \%)$ dan penghasilan kurang dari $\operatorname{Rp~1.000.000,00~(75,4\% ~dan~72,5\% ).~Sementara~}$ itu, hanya sebagian kecil subjek pada kasus dan kontrol yang mengkonsumsi rokok (6,5\%), mengkonsumsi minuman beralkohol $(3,6 \%)$, dan yang menjalani terapi obat antihipertensi (15,9\%) (Tabel 1).

Subjek penelitian pada kelompok kasus menunjukkan bahwa sebagian besar memiliki asupan tinggi $\mathrm{Na}(78,3 \%)$, asupan $\mathrm{K}$ rendah $(89,9 \%)$, asupan $\mathrm{Ca}$ rendah (79,7\%), dan asupan rendah $\mathrm{Mg}(82,6 \%)$. Hasil analisis dengan uji Chi-Square menunjukkan bahwa terdapat hubungan yang bermakna antara asupan $\mathrm{Na}$, asupan $\mathrm{K}$, asupan $\mathrm{Ca}$, dan asupan $\mathrm{Mg}$ dengan status overweight dan tidak overweight pada lansia penderita hipertensi esensial $(\mathrm{p}<0,05)$ (Tabel 2). Hasil analisis juga menunjukkan bahwa lansia penderita hipertensi esensial dengan asupan $\mathrm{Na}$ yang tinggi serta asupan $\mathrm{K}, \mathrm{Ca}$, dan $\mathrm{Mg}$ yang rendah, secara berturut-turut memiliki risiko 
Tabel 2. Hasil analisis hubungan antara asupan mikronutrien ( $\mathrm{Na}, \mathrm{K}, \mathrm{Ca}, \mathrm{Mg}$ ) pada lansia penderita hipertensi esensial terhadap status gizi overweight dan tidak overweight

\begin{tabular}{|c|c|c|c|c|c|c|c|}
\hline \multirow{3}{*}{ Asupan } & \multicolumn{4}{|c|}{ Status gizi } & \multirow{3}{*}{ OR } & \multirow{3}{*}{$95 \%$ CI } & \multirow{3}{*}{$\mathbf{p}$} \\
\hline & \multicolumn{2}{|c|}{ Kasus } & \multicolumn{2}{|c|}{ Kontrol } & & & \\
\hline & $\mathbf{n}$ & $\%$ & $\mathbf{n}$ & $\%$ & & & \\
\hline \multicolumn{8}{|l|}{$\mathrm{Na}$} \\
\hline Tinggi ( $\geq 2300 \mathrm{mg} /$ hari) & 54 & 78,3 & 28 & 40,6 & 5,271 & $2,497-11,127$ & $0,000^{*}$ \\
\hline Rendah (<2300 mg/hari) & 15 & 21,7 & 41 & 59,4 & & & \\
\hline \multicolumn{8}{|l|}{$\mathrm{K}$} \\
\hline Rendah (<2000 mg/hari) & 62 & 89,9 & 39 & 56,5 & 6,813 & $2,729-17,012$ & $0,000^{*}$ \\
\hline Tinggi ( $\geq 2000 \mathrm{mg} / \mathrm{hari})$ & 7 & 10,1 & 30 & 43,5 & & & \\
\hline \multicolumn{8}{|l|}{$\mathrm{Ca}$} \\
\hline $\begin{array}{l}\text { Rendah } \\
(<800 \mathrm{mg} / \text { hari atau }<600 \mathrm{mg} / \text { hari })\end{array}$ & 55 & 79,7 & 37 & 53,6 & 3,398 & $1,599-7,220$ & $0,001 *$ \\
\hline $\begin{array}{l}\text { Tinggi } \\
(\geq 800 \mathrm{mg} / \text { hari atau } \geq 600 \mathrm{mg} / \text { hari })\end{array}$ & 14 & 20,3 & 32 & 46,4 & & & \\
\hline \multicolumn{8}{|l|}{$\mathrm{Mg}$} \\
\hline $\begin{array}{l}\text { Rendah } \\
(<280 \mathrm{mg} / \text { hari atau }<250 \mathrm{mg} / \text { hari })\end{array}$ & 57 & 82,6 & 40 & 58,0 & 3,444 & $1,571-7,549$ & $0,002 *$ \\
\hline $\begin{array}{l}\text { Tinggi } \\
(\geq 280 \mathrm{mg} / \text { hari atau } \geq 250 \mathrm{mg} / \text { hari })\end{array}$ & 12 & 17,4 & 29 & 42,0 & & & \\
\hline
\end{tabular}

Keterangan: $*=$ bermakna $(\mathrm{p}<0,05)$

5,3 kali; 6,8 kali; 3,4 kali; dan 3,4 kali lebih besar untuk memiliki status gizi overweight dibandingkan lansia dengan asupan rendah $\mathrm{Na}$ serta asupan $\mathrm{K}, \mathrm{Ca}$, dan $\mathrm{Mg}$ yang tinggi.

Hasil uji regresi logistik menunjukkan bahwa asupan Na dan $\mathrm{K}$ merupakan dua variabel yang paling berpengaruh pada kejadian hipertensi esensial pada lansia yang overweight dan tidak overweight $(\mathrm{p}=0,000)$ (Tabel 3, tahap 1). Langkah selanjutnya adalah melakukan analisis regresi logistik lanjutan yang dilaksanakan secara bertahap, yaitu dengan mengeluarkan variabel yang mempunyai nilai p yang paling besar pada setiap tahapnya. Berdasarkan hasil akhir diketahui bahwa asupan $\mathrm{Na}$ dan $\mathrm{K}$ secara bersama-sama memiliki hubungan yang bermakna pada lansia penderita hipertensi esensial yang overweight dengan lansia yang tidak overweight $(\mathrm{p}<0,05)$ (Tabel 3, tahap 2). Seperti diketahui bahwa Na dan K dalam bentuk ion, berperan bersama-sama dalam menjaga keseimbangan cairan tubuh, baik cairan ekstraseluler maupun intraseluler. Penatalaksanaan hipertensi selain dengan terapi obat antihipertensi adalah penatalaksanaan asupan makanan dengan mengurangi asupan $\mathrm{Na}$ dan meningkatkan asupan $\mathrm{K}$ (7). Hasil analisis dengan uji t menunjukkan bahwa terdapat perbedaan yang bermakna pada asupan $\mathrm{Na}$, asupan
Tabel 3. Hasil analisis multivariat regresi logistik tahap 1 dan 2

\begin{tabular}{lccc}
\hline Variabel & Exp (B) & $\mathbf{9 5 \%}$ CI & Sig. \\
\hline Tahap 1 & & & \\
Asupan $\mathrm{Na}$ & 4,878 & $2,101-11,326$ & $0,000^{*}$ \\
Asupan $\mathrm{K}$ & 0,155 & $0,055-0,439$ & $0,000^{*}$ \\
Asupan $\mathrm{Ca}$ & 0,376 & $0,155-0,910$ & $0,030^{*}$ \\
$\quad$ Asupan $\mathrm{Mg}$ & 0,276 & $0,111-0,686$ & $0,006^{*}$ \\
Tahap 2 & & & \\
Asupan Na & 4,923 & $2,148-11,283$ & $0,000^{*}$ \\
Asupan K & 0,15 & $0,055-0,407$ & $0,000^{*}$ \\
\hline
\end{tabular}

Keterangan: $*=$ bermakna $(\mathrm{p}<0,05)$

$\mathrm{K}$, asupan $\mathrm{Ca}$, dan asupan $\mathrm{Mg}$ antara lansia penderita hipertensi esensial yang overweight dengan lansia yang tidak overweight $(\mathrm{p}<0,05)$ (Tabel 4).

\section{BAHASAN}

\section{Karakteristik subjek penelitian}

Karakteristik subjek penelitian berdasarkan pekerjaan, pendidikan, dan pendapatan menunjukkan bahwa tidak ada perbedaan yang bermakna antara lansia penderita hipertensi esensial yang overweight dan tidak overweight. Sebagian besar subjek penelitian ini bekerja 
Catur Saptaning Wilujeng, dkk: Perbedaan asupan mikronutrien pada lansia penderita hipertensi esensial yang overweight dan tidak overweight

Tabel 4. Hasil analisis perbedaan asupan mikronutrien ( $\mathrm{Na}, \mathrm{K}, \mathrm{Ca}, \mathrm{Mg}$ ) pada lansia penderita hipertensi esensial antara yang overweight dibandingkan dengan yang tidak overweight

\begin{tabular}{|c|c|c|c|c|c|}
\hline $\begin{array}{c}\text { Asupan } \\
\text { (mg) }\end{array}$ & $\begin{array}{c}\text { Kasus } \\
\text { Rerata }( \pm \text { SD })\end{array}$ & $\begin{array}{c}\text { Kontrol } \\
\text { Rerata }( \pm \text { SD) }\end{array}$ & $\Delta$ Rerata & $95 \%$ CI & p \\
\hline $\mathrm{Na}$ & $2421,3( \pm 124,3)$ & $2293,1( \pm 81,1)$ & 128,2 & 91,$9 ; 164,1$ & $0,000 *$ \\
\hline $\mathrm{K}$ & $1948,3( \pm 119,7)$ & $2078,2( \pm 178,2)$ & $-129,9$ & $-184,2 ;-74,8$ & $0,000 *$ \\
\hline $\mathrm{Ca}$ & $522,7( \pm 113,2)$ & $569,4( \pm 107,3)$ & $-46,7$ & $-83,5 ;-9,9$ & $0,014 *$ \\
\hline $\mathrm{Mg}$ & $240,6( \pm 28,1)$ & $258,3( \pm 39,7)$ & $-17,7$ & $-29,4 ;-6,1$ & $0,003 *$ \\
\hline
\end{tabular}

Keterangan: * = bermakna $(\mathrm{p}<0,05)$

sebagai non PNS, tingkat pendidikan tergolong rendah, dan penghasilan kurang dari Rp 1.000.000,00. Di negaranegara yang berada pada tahap pasca peralihan perubahan ekonomi dan epidemiologi, selalu dapat ditunjukkan bahwa tekanan darah dan prevalensi hipertensi yang lebih tinggi terdapat pada golongan sosio-ekonomi rendah. Hubungan terbalik ini ternyata berkaitan dengan tingkat pendidikan, penghasilan, dan pekerjaan (12). Hasil penelitian di Korea (13) juga menyebutkan bahwa subjek yang memiliki tekanan darah normal (tidak hipertensi) adalah subjek dengan tingkat pendidikan tinggi sedangkan sebagian besar subjek dengan tingkat pendidikan rendah menderita hipertensi $(65,1 \%)$. Keadaan sosio-ekonomi yang baik dapat meningkatkan rasa nyaman dan kualitas hidup lansia. Lansia yang memiliki pendidikan dan pendapatan yang tinggi akan lebih sadar tentang cara menjaga kesehatan, misalnya dengan chek-up kesehatan rutin dan memilih makanan yang sehat, baik dari segi kualitas dan kuantitasnya sehingga menurunkan risiko untuk terkena penyakit dan faktor-faktor risiko yang menyebabkan penyakit tersebut.

Hasil penelitian ini juga menunjukkan bahwa tidak ada perbedaan yang bermakna pada terapi obat antihipertensi, konsumsi rokok, dan konsumsi minuman beralkohol antara lansia penderita hipertensi esensial yang overweight dan tidak overweight. Pada penelitian ini, terapi obat antihipertensi tidak memiliki perbedaan yang bermakna karena sebagian besar lansia tidak menjalankan terapi obat antihipertensi. Banyaknya lansia yang tidak menjalankan terapi obat hipertensi ini kemungkinan disebabkan oleh timbulnya rasa bosan dan malas pada lansia karena harus mengkonsumsi obat antihipertensi dalam jangka waktu yang lama untuk mengendalikan tekanan darah. Sebagian besar subjek penelitian ini berjenis kelamin perempuan $(73,9 \%)$. Di
DIY tidak lazim atau dianggap tidak sopan dan tidak sesuai dengan budaya apabila perempuan merokok sehingga semua lansia perempuan yang menjadi subjek penelitian ini tidak merokok. Demikian juga sebagian besar subjek menyatakan bahwa tidak mengkonsumsi minuman beralkohol. Alasan utama yang disebutkan oleh subjek penelitian ini adalah alasan keagamaan bahwa mengkonsumsi minuman beralkohol bertentangan dengan ajaran agama.

\section{Perbedaan asupan Na pada lansia penderita hipertensi esensial antara yang overweight dengan yang tidak overweight}

Hasil penelitian ini menunjukkan bahwa terdapat perbedaan asupan Na yang bermakna $(p<0,05)$ antara lansia penderita hipertensi esensial yang overweight dengan yang tidak overweight. Asupan Na tinggi jumlahnya lebih banyak ditemukan pada kelompok lansia yang overweight dibandingkan dengan kelompok lansia yang tidak overweight. Selain itu, hasil analisis juga menunjukkan bahwa terdapat hubungan bermakna asupan Na pada lansia penderita hipertensi esensial yang overweight dengan yang tidak overweight. Penelitian ini sejalan dengan penelitian di China (14) yang menunjukkan bahwa monosodium glutamat (MSG) merupakan salah satu sumber Na yang secara bermakna berkorelasi dengan body mass indeks (BMI). Hal ini akan meningkatkan risiko terjadinya overweight dan seperti diketahui bahwa overweight atau obesitas merupakan faktor risiko terjadinya penyakit hipertensi. Lebih lanjut, penelitian lain yang dilakukan di China (15) menyatakan bahwa prevalensi tekanan darah di China bagian utara lebih tinggi dibandingkan dengan prevalensi tekanan darah di China bagian selatan. Rerata tekanan darah 
sistolik/diastolik yang terukur pada orang-orang di China bagian utara 7,4/6,9 mmHg lebih tinggi daripada orang-orang di China bagian selatan. Hal ini disebabkan orang-orang China bagian selatan yang berpastisipasi dalam penelitian memiliki IMT yang rendah, asupan Na yang rendah, dan rasio $\mathrm{Na} / \mathrm{K}$ yang rendah.

Perbedaan asupan $\mathrm{Na}$ yang bermakna antara lansia penderita hipertensi esensial yang overweight dengan yang tidak overweight ini mungkin disebabkan oleh penggunaan sumber Na dalam jumlah yang banyak sebagai penyedap makanan (terutama rasa asin), misalnya MSG untuk menggugah nafsu makan. Seperti halnya hasil penelitian di Cina (14) yaitu prevalensi overweight meningkat pada pengguna MSG dibandingkan dengan orang yang tidak menggunakan MSG. Penelitian tersebut juga menyatakan bahwa hubungan positif antara konsumsi MSG dengan overweight mungkin merupakan hasil dari rasa yang kuat dari penggunaan MSG dalam jumlah banyak sehingga adanya rangsangan pada leptin resistance yang akan meningkatkan rangsangan nafsu makan.

Seseorang yang sudah mulai lanjut usia, akan mengalami beberapa gangguan atau ketidakseimbangan fisik dan mental. Beberapa gangguan fisik yang dialami lansia karena proses penuaan misalnya adalah masalah status gizi dan gangguan panca indera. Orang yang sudah lanjut usia sering menderita kurang gizi atau gizi berlebih (overweight dan obesitas). Status gizi berlebih ini bisa terjadi mungkin karena lansia sudah jarang melakukan aktivitas fisik atau olahraga akibat keterbatasan mereka (lemah, tidak bisa berjalan lagi, atau karena sakit tertentu) atau pola hidup sejak usia muda yang mungkin memang susah makan sehingga mengalami kurang gizi atau bahkan makan berlebihan sehingga menyebabkan overweight dan obesitas (1). Berat badan yang berlebih (overweight dan obesitas) akan membuat seseorang susah bergerak dengan bebas. Jantungnya harus bekerja lebih keras untuk memompa darah agar bisa menggerakkan tubuh secara berlebihan, oleh karena itu overweight dan obesitas merupakan salah satu faktor yang bisa meningkatkan risiko terjadinya hipertensi (16). Seperti juga hasil penelitian di Portugal yang menyebutkan bahwa kenaikan tekanan darah seiring dengan kenaikan IMT (17).
Gangguan panca indera yang dialami oleh lansia salah satunya adalah gangguan indera perasa atau gangguan kemampuan menikmati cita rasa makanan. Indera yang paling banyak terganggu adalah indera pengecap rasa manis dan rasa asin. Sensitivitas terhadap rasa manis dan asin biasanya berkurang (18). Oleh karena itu, lansia lebih senang mengkonsumsi makanan yang asin sehingga terkadang penggunaan garam atau $\mathrm{Na}$ berlebihan dan tidak terkontrol. Ketidaksadaran lansia menyukai makanan asin inilah yang membuat lansia berlebihan dalam penggunaan garam (sumber $\mathrm{Na}$ ) dan makanan-makanan yang diawetkan seperti sarden, telur asin, biskuit, crackers, serta bumbu-bumbu penyedap seperti MSG, kecap, saus, dan tauco. Penggunaan bumbu penyedap serta mengkonsumsi makanan yang diawetkan dengan garam dapur dalam jumlah yang banyak dapat meningkatkan tekanan darah karena mengandung $\mathrm{Na}$ dalam jumlah yang berlebih (16).

\section{Perbedaan asupan K pada lansia penderita hipertensi esensial antara yang overweight dengan yang tidak overweight}

Hasil penelitian ini menunjukkan bahwa terdapat perbedaan asupan $\mathrm{K}$ yang bermakna $(\mathrm{p}<0,05)$ antara lansia penderita hipertensi esensial yang overweight dengan yang tidak overweight. Asupan $\mathrm{K}$ rendah lebih banyak ditemukan pada kelompok lansia yang overweight dibandingkan dengan kelompok lansia yang tidak overweight. Hasil penelitian ini juga menunjukkan bahwa terdapat hubungan bermakna asupan $\mathrm{K}$ pada lansia penderita hipertensi esensial yang overweight dengan yang tidak overweight. Berdasarkan data Riskesdas tahun 2007, prevalensi kurang makan buah dan sayur (konsumsi buah dan sayur kurang dari 5 porsi per hari selama 7 hari dalam seminggu) di DIY menduduki peringkat kedua $(86,1 \%)$ dari prevalensi nasional $(93,6 \%)$. Sementara itu, sumber kalium paling banyak berasal dari sayur-sayuran, buah-buahan, dan kacang-kacangan. Berdasarkan hasil wawancara, lansia memang mengkonsumsi buah dan sayur tetapi dalam porsi kecil dan frekuensinya jarang. Lansia lebih suka mengkonsumsi sumber protein (tahu, tempe, daging, ayam, telur) dan lemak yang rasanya lebih gurih. Selain itu, mungkin bisa disebabkan oleh pengolahan sayuran yang kurang tepat sehingga kadar K 
pada sayuran menjadi berkurang. Di samping itu, organ pencernaan pada lansia sudah mengalami gangguan sehingga tidak maksimal dalam menyerap $\mathrm{K}$ dari makanan.

Menurut data National Health and Nutrition Examination Survey (NHANES) tahun 1999-2002 menyatakan bahwa konsumsi kacang polong berhubungan dengan penurunan risiko peningkatan obesitas dibandingkan dengan orang yang tidak mengkonsumsi kacang polong. Perbedaan asupan $\mathrm{K}$ yang bermakna antara lansia penderita hipertensi esensial yang overweight dengan yang tidak overweight ini mungkin karena asupan buah dan sayuran hijau sebagai sumber $\mathrm{K}$ pada lansia yang overweight lebih sedikit dibandingkan dengan lansia yang tidak overweight. Merujuk pada penelitian sebelumnya yang menyebutkan bahwa konsumsi tinggi $\mathrm{K}$ berhubungan dengan penurunan berat badan, maka dapat disimpulkan bahwa pada penelitian ini lansia yang overweight memiliki tingkat konsumsi $\mathrm{K}$ yang rendah sehingga tingkat risiko kenaikan berat badan akan lebih tinggi dibandingkan dengan lansia yang tidak overweight (19).

Menurut teori, $\mathrm{K}$ berbeda dengan $\mathrm{Na}$, K merupakan ion utama dalam cairan intraseluler. Cara kerja $\mathrm{K}$ adalah kebalikan dari Na. Asupan K yang banyak akan meningkatkan konsentrasinya di dalam cairan intraseluler sehingga cenderung menarik cairan dari bagian ekstraseluler dan menurunkan tekanan darah. Oleh karena itu, asupan $\mathrm{Na}$ perlu diimbangi dengan K. Rasio asupan $\mathrm{Na}$ dan $\mathrm{K}$ yang dianjurkan adalah 1:1. Sumber K yang baik adalah buah-buahan, seperti pisang, jeruk, dan lainlain. Secara alami, banyak bahan pangan yang memiliki kandungan $\mathrm{K}$ dengan rasio lebih tinggi dibandingkan dengan Na. Rasio tersebut kemudian menjadi terbalik akibat proses pengolahan yang banyak menambahkan garam $(\mathrm{NaCl})$. Misalnya, rasio $\mathrm{K}$ terhadap $\mathrm{Na}$ buah tomat segar adalah 100:1 menjadi 10:6 pada tomat kaleng bahkan 1:28 pada saus tomat. Contoh lainnya adalah rasio $\mathrm{K}$ terhadap Na pada kentang bakar 100:1 menjadi 10:9 pada keripik dan 1:1,7 pada salad kentang. Hal ini menunjukkan bahwa proses pengolahan menyebabkan tingginya kadar Na dalam bahan makanan sehingga cenderung meningkatkan tekanan darah (16).

\section{Perbedaan asupan Ca pada lansia penderita hipertensi esensial antara yang overweight dengan yang tidak overweight}

Hasil penelitian ini menunjukkan bahwa terdapat perbedaan asupan $\mathrm{Ca}$ yang bermakna $(\mathrm{p}<0,05)$ antara lansia penderita hipertensi esensial yang overweight dengan lansia yang tidak overweight. Kelompok lansia yang overweight dengan asupan $\mathrm{Ca}$ rendah jumlahnya lebih banyak dibandingkan dengan kelompok lansia yang tidak overweight. Selain itu, hasil analisis menunjukkan bahwa terdapat hubungan bermakna asupan Ca pada lansia penderita hipertensi esensial yang overweight dengan yang tidak overweight. Hasil penelitian ini didukung oleh penelitian di Israel (20) yang menyimpulkan bahwa terdapat hubungan bermakna antara konsumsi Ca sehari-hari dengan lingkar pinggang pada wanita. Wanita yang mempunyai lingkar pinggang kurang dari $88 \mathrm{~cm}$, mengkonsumsi Ca sehari-hari lebih tinggi dibandingkan dengan wanita yang memiliki lingkar pinggang lebih dari $88 \mathrm{~cm}$. Kalsium berperan dalam regulasi berat badan dengan mempengaruhi $\mathrm{Ca}$ intraseluler dari jaringan adiposa. Selain itu, Ca juga mengurangi sintesis asam lemak dengan meningkatkan pemecahan lemak dalam tubuh. Penelitian lain di China (15) menyebutkan bahwa rerata tekanan darah sistolik/diastolik yang terukur pada orang-orang di China bagian utara 7,4/6,9 mm Hg lebih tinggi daripada orang-orang di China bagian selatan. Hal ini terjadi karena orang-orang di China bagian selatan memiliki IMT yang rendah dan tinggi asupan $\mathrm{Ca}$, fosfor (P), vitamin A, dan vitamin C.

Kalsium banyak terdapat pada susu dan hasil olahannya; ikan, udang, kerang, dan kepiting; kacangkacangan dan hasil olahannya; daun singkong; dan daun lamtoro (21). Perbedaan asupan Ca yang bermakna pada lansia penderita hipertensi esensial yang overweight dengan yang tidak overweight pada penelitian ini mungkin disebabkan oleh konsumsi $\mathrm{Ca}$ yang rendah pada lansia yang overweight. Susu sebagai sumber Ca yang baik malah sering dihindari oleh lansia karena adanya ketakutan akan bertambah gemuk sehingga hal ini menjadi salah satu faktor yang menyebabkan perbedaan asupan Ca pada lansia yang overweight dan tidak overweight. 
Seiring dengan bertambahnya umur menyebabkan perubahan kemampuan dalam mengecap, mencerna, menyerap, dan memetabolisme makanan sehingga berdampak pada penurunan kadar $\mathrm{Ca}$ di dalam tubuh. Pada usia muda, bila asupan $\mathrm{Ca}$ rendah akan terjadi defisiensi atau peningkatan dalam absorbsi yang tidak terjadi pada lansia. Pada usia lanjut, kemampuan ginjal untuk mensintesis $1,25-(\mathrm{OH})_{2}$ vitamin D sebagai respon terhadap hormon paratiroid menurun. Selain itu, usus lansia juga kurang responsif terhadap sinyal $1,25-(\mathrm{OH})_{2}$ vitamin D untuk meningkatkan absorbsi Ca. Kulit lansia juga mengalami penurunan kemampuan untuk mensintesis prokolekalsiferol yang diubah menjadi vitamin D dengan bantuan sinar ultraviolet (1). Jadi, dapat disimpulkan bahwa lansia dengan asupan $\mathrm{Ca}$ rendah mungkin berhubungan dengan penurunan respon intestinum terhadap vitamin $\mathrm{D}$ sehingga jika vitamin $\mathrm{D}$ dalam tubuh berkurang maka absorbsi $\mathrm{Ca}$ juga akan berkurang atau rendah. Hal ini bisa menjadi faktor lain penyebab perbedaan asupan $\mathrm{Ca}$ antara lansia penderita hipertensi esensial yang overweight dan tidak overweight.

\section{Perbedaan asupan Mg pada lansia penderita hipertensi esensial antara yang overweight dengan yang tidak overweight}

Hasil penelitian ini menunjukkan bahwa terdapat perbedaan asupan $\mathrm{Mg}$ yang bermakna $(\mathrm{p}<0,05)$ antara lansia penderita hipertensi esensial yang overweight dengan yang tidak overweight. Kelompok lansia yang overweight dengan asupan Mg rendah jumlahnya lebih banyak dibandingkan dengan kelompok lansia yang tidak overweight. Hasil penelitian ini juga menunjukkan bahwa terdapat hubungan bermakna asupan Mg pada lansia penderita hipertensi esensial yang overweight dengan yang tidak overweight. Sejalan dengan penelitian di Amerika Serikat (22) yang menyatakan adanya hubungan bermakna antara asupan $\mathrm{Ca}$ dan Mg dengan metabolic disorders termasuk obesitas. Magnesium berperan dalam sensitivitas insulin yang mempengaruhi gula darah dalam tubuh dan berpengaruh pada rangsangan rasa lapar. Penelitian lain di China (15) yang sejalan dengan penelitian ini menyimpulkan bahwa prevalensi tekanan darah di China bagian utara lebih besar dibandingkan dengan prevalensi tekanan darah di China bagian selatan karena orang-orang di China bagian selatan memiliki IMT yang rendah dan tinggi asupan $\mathrm{Mg}, \mathrm{P}$, vitamin A, dan vitamin C.

Sumber utama Mg adalah sayuran hijau, serelia tumbuk, biji-bijian, kacang-kacangan, daging, susu, dan hasil olahannya, serta cokelat (21). Sumber Mg hampir sama dengan sumber $\mathrm{K}$ dan $\mathrm{Ca}$. Lansia pada penelitian ini memiliki asupan $\mathrm{Mg}$ yang rendah seiring dengan rendahnya asupan $\mathrm{K}$ dan asupan $\mathrm{Ca}$. Hal ini karena lansia sangat kurang dalam mengkonsumsi buah dan sayur (sebagai sumber $\mathrm{K}$ dan $\mathrm{Mg}$ ) serta susu dan hasil olahannya (sebagai sumber $\mathrm{Ca}$ dan $\mathrm{Mg}$ ). Asupan $\mathrm{Mg}$, asupan $\mathrm{K}$, dan asupan Ca akan saling berhubungan karena sumber makanannya hampir sama sehingga apabila asupan $\mathrm{K}$ rendah maka asupan Mg juga akan rendah dan apabila asupan $\mathrm{Ca}$ rendah maka asupan Mg juga rendah. Oleh karena itu, jika asupan K dan Ca berbeda maka asupan Mg juga akan ikut berbeda pada lansia penderita hipertensi esensial antara yang overweight dan yang tidak overweight.

Perbedaan asupan mikronutrien ( $\mathrm{Na}, \mathrm{K}, \mathrm{Ca}, \mathrm{Mg}$ ) yang bermakna pada lansia penderita hipertensi esensial yang overweight dibandingkan dengan yang tidak overweight disebabkan oleh beberapa faktor. Penjelasan yang terkait dengan penelitian ini adalah bahwa overweight dan obesitas merupakan salah satu faktor risiko terjadinya hipertensi. Lansia yang overweight dan memiliki asupan Na tinggi akan meningkatkan risiko terkena hipertensi. Sebuah penelitian menyatakan bahwa IMT yang tinggi $\left(>23 \mathrm{~kg} / \mathrm{m}^{2}\right)$ berhubungan bermakna dengan risiko hipertensi (13). Penelitian lain pada lansia yang tidak overweight (normal-weight) dan berat badan lebih (overweight), menunjukkan bahwa asupan $\mathrm{Na}$ merupakan faktor yang menentukan tekanan darah pada lansia yang tidak overweight sedangkan asupan $\mathrm{K}$ dan $\mathrm{Ca}$ merupakan faktor yang menentukan tekanan darah pada lansia yang overweight (23). Ada perbedaan ekskresi $\mathrm{Na}$ dan K melalui urin pada kelompok dengan IMT yang tinggi $\left(>23 \mathrm{~kg} / \mathrm{m}^{2}\right)$ dibandingkan kelompok dengan IMT yang normal $\left(18,50-22,9 \mathrm{~kg} / \mathrm{m}^{2}\right)(24)$.

Hasil penelitian ini menunjukkan bahwa terdapat perbedaan yang bermakna asupan $\mathrm{Na}, \mathrm{K}, \mathrm{Ca}$, dan $\mathrm{Mg}$ pada lansia penderita hipertensi esensial yang overweight dibandingkan dengan yang tidak overweight. Namun, jika dilihat dari rerata asupannya menunjukkan bahwa 
asupan $\mathrm{Na}, \mathrm{Ca}$, dan $\mathrm{Mg}$ masih tergolong kurang baik bagi penderita hipertensi terutama lansia dengan status overweight, tetapi asupan $\mathrm{K}$ dapat dikatakan sudah baik apabila dibandingkan dengan angka kecukupan gizi (AKG) 2012 untuk orang Indonesia (25).

Hasil analisis menunjukkan bahwa asupan Na dan $\mathrm{K}$ adalah dua mikronutrien yang paling berpengaruh pada kejadian hipertensi pada lansia yang overweight maupun yang tidak overweight. Hal ini terkait dengan kebiasaan dan pola makan lansia di Yogyakarta yang menyukai makanan asin (makanan tinggi $\mathrm{Na}$ ) dan kurangnya asupan sayur-sayuran yang merupakan sumber bahan makanan tinggi K. Pengaturan makan untuk penderita hipertensi adalah dengan mengurangi asupan $\mathrm{Na}$, meningkatkan asupan $\mathrm{K}$, asupan $\mathrm{Ca}$, dan asupan $\mathrm{Mg}$ (7). Asupan $\mathrm{Na}$ untuk lansia dibatasi yaitu tidak melebihi $1300 \mathrm{mg}$ per hari untuk laki-laki dan $1200 \mathrm{mg}$ per hari untuk perempuan. Sementara itu, batasan asupan K yaitu $4700 \mathrm{mg}$ per hari dan asupan Ca $1000 \mathrm{mg}$ per hari bagi laki-laki maupun perempuan, serta asupan Mg yaitu $350 \mathrm{mg}$ per hari bagi laki-laki dan $320 \mathrm{mg}$ per hari bagi perempuan (25).

Penatalaksanaan penyakit hipertensi pada lansia adalah berbeda antara lansia yang satu dengan lainnya, baik mengenai pemberian dosis obat sampai penatalaksanaan makanannya (1). Oleh karena itu, dapat disimpulkan bahwa lansia penderita hipertensi esensial yang overweight akan berbeda penanganannya baik dari segi pemberian dosis obat maupun penatalaksanaan asupan makanan sehari-hari dibandingkan dengan lansia penderita hipertensi esensial yang tidak overweight. Dapat dikatakan bahwa dosis obat dan jumlah atau jenis obat yang yang diberikan pada lansia penderita hipertensi esensial yang overweight lebih banyak dibandingkan dengan lansia penderita hipertensi esensial yang tidak overweight. Demikian juga dengan penatalaksanaan asupan makanan sehari-hari, tujuan dan jumlahnya pun juga akan berbeda yaitu untuk lansia yang overweight tujuannya adalah untuk menurunkan tekanan darah dan menurunkan berat badan. Berbeda dengan lansia yang tidak overweight, tujuan dan jumlah penatalaksanaan makanan sehari-hari adalah untuk menurunkan tekanan darah dan mempertahankan status gizi agar tetap pada status gizi normal sehingga tidak menjadi status gizi lebih (overweight dan obesitas) atau lebih buruk menjadi status gizi kurang.

\section{SIMPULAN DAN SARAN}

Berdasarkan hasil penelitian dapat disimpulkan bahwa terdapat perbedaan yang bermakna asupan $\mathrm{Na}, \mathrm{K}$, $\mathrm{Ca}$, dan Mg pada lansia penderita hipertensi esensial yang overweight dibandingkan dengan yang tidak overweight. Lansia penderita hipertensi esensial yang memiliki asupan $\mathrm{Na}$ tinggi, $\mathrm{K}$ rendah, $\mathrm{Ca}$ rendah, dan $\mathrm{Mg}$ rendah berisiko lebih besar untuk memiliki status gizi overweight dibandingkan dengan lansia yang memiliki asupan $\mathrm{Na}$ rendah, $\mathrm{K}$ tinggi, $\mathrm{Ca}$ tinggi, dan $\mathrm{Mg}$ tinggi.

Terkait dengan pencegahan hipertensi di masyarakat terutama kelompok masyarakat yang memiliki status gizi overweight, dapat dilakukan dengan mendukung rekomendasi untuk mengurangi asupan $\mathrm{Na}$, meningkatkan asupan $\mathrm{K}, \mathrm{Ca}$, dan $\mathrm{Mg}$, serta upaya pengaturan berat badan. Selain itu, diharapkan adanya kerjasama yang baik dan profesional antara Griya Sehat Lansia dan Dinas Kesehatan terkait (Kota dan Provinsi DIY), yaitu dengan mengadakan dan mengembangkan posyandu lansia atau program pelayanan atau pemeriksaan kesehatan rutin, tidak hanya di daerah kota saja tetapi dapat juga menjangkau daerah pedesaan atau daerah yang belum menjadi sasaran binaan Griya Sehat Lansia.

\section{RUJUKAN}

1. Darmojo B, Martono H, Pranarka K. Buku ajar geriatri (ilmu kesehatan usia lanjut). Jakarta: Balai Penerbit FKUI; 2010.

2. Badan Penelitian Pengembangan Kesehatan. Hasil riset kesehatan dasar (Riskesdas) Provinsi Daerah Istimewa Yogyakarta Indonesia - tahun 2007. Jakarta: Departemen Kesehatan Republik Indonesia; 2008.

3. Riyadi A, Wiyono P, Budiningsari RD. Asupan gizi dan status gizi sebagai faktor risiko hipertensi esensial pada lansia di Puskesmas Curup dan Perumnas Kabupaten Rejang Lebong Provinsi Bengkulu. Jurnal Gizi Klinik Indonesia 2007;4(1):43-51.

4. $\mathrm{Hu} \mathrm{G}$, Tian H. A Comparison of dietary and non-dietary factors of hypertension and normal blood pressure in a Chinese population. J Hum Hypertens 2001;15(7):487-93.

5. Sastroasmoro S, Ismael S. Dasar-dasar metodologi penelitian klinis. Jakarta: Binarupa Aksara; 1995.

6. Institute of Medicine. Blood pressure: policy - sodium. Institute of Medicine: Canada; 2003.

7. Widya Karya Pangan Nasional Pangan dan Gizi Ke-7. Angka kecukupan gizi tahun 2004 bagi orang Indonesia. Jakarta: PT Primamedia Pustaka; 2006. 
8. Inoue S, Zimmet P, Caterson I, Chunming C, Ikeda Y, Khalid AK, Kim YS, Basset J. The Asia-Pasific perspective: redefining obesity and its treatment. Australia: Health Communication; 2000.

9. JNC VII: The seventh report of the joint committee on prevention, detection, evaluation, and treatment of high blood pressure. NIH Publication No. 04-5230; 2004.

10. WHO. Pengendalian hipertensi: laporan komisi pakar WHO. Bandung: Penerbit ITB; 2001.

11. Lee JS, Park J, Kim J. Dietary factors related to hypertension risk in Korea adults-data from the Korean national health and nutrition examination survey III. Nutr Res Pract 2011;5(1);60-5.

12. He K, Zhao L, Daviglus ML, Dyer AR, Horn LV, Garside D, Zhu L, Guo D, Wu Y, Zhou B, Stamler J. Association of monosodium glutamate intake with overweight in Chinese adults: the INTERMAP Study. Obesity 2008;16(8):187580 .

13. Zhao L, Stmaler J, Yan LL, Zhou B, Wu Y, Liu K, Daviglus ML, Dennis BH, Elliott P, Ueshima H, Yang J, Zhu L, Guo D. Blood pressure differences between northern and southern Chinese: role of dietary factors: the international study on macronutrients and blood pressure. Hypertension 2004;43:1332-7.

14. Muhammadun. Hidup bersama hipertensi. Yogyakarta: In-Books; 2010.

15. Santos A, Martins MJ, Guimaraes JT, Severo M, Azevedo I. Sodium-rich carbonated natural mineral water ingestion and blood pressure. Rev Port Cardiol 2010;29(2):159-72.

16. Almatsier S. Gizi seimbang untuk usia tua di dalam hidup sehat gizi seimbang dalam siklus kehidupan manusia. Soekirman, Susana H, Giarno MH, Lestari Y, editor. Jakarta: PT Primamedia Pustaka Anggota IKAPI; 2006.

17. Papanikolaou Y, Fulgoni VL. Bean consumption is associated with greater nutrient intake, reduced systolic blood pressure, lower body weight, and a smaller waist circumference in adults: results from the National Health and Nutrition Examination Survey 1999-2002. J Am Coll Nutr 2008;27(5):569-76.

18. Dicker D, Belnic Y, Goldsmith R, Kaluski DN. Relationship between dietary calcium intake, body mass index, and waist circumference in MABAT-the Israeli National Health and Nutrition Study. Isr Med Assoc J 2008;10(7):512-5.

19. Almatsier S. Prinsip-prinsip dasar ilmu gizi. Jakarta: Gramedia; 2003.

20. Beydoun MA, Gary TL, Caballero BH, Lawrence RS, Cheskin LJ, Wang Y. Ethnic differences in diary and related nutrient consumption among US adults and their association with obesity, central obesity, and the metabolic syndrome. Am J Clin Nutr 2008;87(6):1914-25.

21. Kamso S, Rumawas J, Lukito W, Purwantyastuti. Determinants of blood pressure among indonesian elderly individuals who are of normal and over-weight: a cross sectional study in urban population. Asia Pac J Clin Nutr 2007;16(3):546-53.

22. Dyer AR, Elliott P, Shipley M, Stamler R, StamlernJ. Body mass index and associations of sodium and potassium with blood pressure in INTERSALT. Hypertension 1994;23(6 Pt 1):729-36.

23. Peraturan Menteri Kesehatan Republik Indonesia Nomor 75 tentang Angka Kecukupan Gizi yang Dianjurkan Bagi Bangsa Indonesia; 2013.

24. Tejasari, Suwardiyanto A, Ningtyas FW. Pengaruh positif formula garam multimineral (MM) pada penderita hipertensi. Gizi Indon 2013;36(1):27-36.

25. Anonim. Data statistik Indonesia tentang estimasi angka harapan hidup menurut provinsi. [series online] 2010 [cited 2010 Okt 16]. Available from: URL: http://www. datastatistikindonesia.com/portal/index.php 